\title{
Impact of subsurface rock fragments on runoff and interrill soil loss from cultivated soils
}

\author{
Toon Smets ${ }^{1,2^{*}}$, Manuel López-Vicente ${ }^{1,3}$ and Jean Poesen ${ }^{1}$ \\ ${ }^{1}$ Department of Earth and Environmental Sciences, Catholic University of Leuven, Geo-Institute. \\ Celestijnenlaan 200E, 3001 Heverlee, Belgium \\ ${ }^{2}$ Department of Transition Energy and Environment, Flemish Institute for Technological Research (VITO), \\ Boeretang 200, 2400 Mol, Belgium \\ ${ }^{3}$ Department of Soil and Water, EEAD-CSIC. Avda. Montañana 1005, 50059 Zaragoza, Spain
}

${ }^{*}$ Correspondence to: Dr. Toon Smets. E-mail: toon.smets@vito.be, smetstoon@hotmail.com, Tel: +32 14335965

Dr. Manuel López-Vicente. E-mail: mvicente@eead.csic.es, Tel: +34 976716161

Dr. Jean Poesen. E-mail: Jean.Poesen@ees.kuleuven.be, Tel: +32 16326425

\begin{tabular}{ll}
\hline - Received & 16 February 2011 \\
Received in revised form & 25 June 2011 \\
Accepted & 11 July 2011 \\
- Published online (uncorrected proof DOI: 10.1002/esp.2220) in Wiley Online Library & 9 August 2011 \\
Published online (corrected proof DOI: 10.1002/esp.2220) in Wiley Online Library & 2 September 2011 \\
\hline Published in Earth Surface Processes and Landforms 36(14): 1929-1937 & November 2011 \\
\hline
\end{tabular}

\begin{abstract}
Field and laboratory studies have indicated that rock fragments in the topsoil may have a large impact on soil properties, soil quality, hydraulic, hydrological and erosion processes. In most studies, the investigated rock fragments still remain visible at the soil surface and only properties of these visible rock fragments are used for predicting runoff and soil loss. However, there are indications that rock fragments completely incorporated in the topsoil could also significantly influence the percolation and water distribution in stony soils and therefore, also infiltration, runoff and soil loss rates. Therefore, in this study interrill laboratory experiments with simulated rainfall during $60 \mathrm{~min}$ were conducted to assess the influence of subsurface rock fragments, incorporated in a disturbed silt loam soil at different depths below the soil surface (i.e. $0.001,0.01,0.05$ and $0.10 \mathrm{~m}$ ), on infiltration, surface runoff and interrill erosion processes for small and large rock fragment sizes (i.e. mean largest diameter equals 0.04 and $0.20 \mathrm{~m}$, respectively). Although only small differences in infiltration rate and runoff volume are observed between the soil without rock fragments (control) and the one with subsurface rock fragments, considerable differences in total interrill soil loss are observed between the control treatment and both contrasting rock fragments sizes. This is explained by a rapid increase in soil moisture in the areas above the rock fragments and
\end{abstract}


therefore a decrease in topsoil cohesion compared to a control soil profile. The observed differences in runoff volume and interrill soil loss between the control plots and those with subsurface rock fragments is largest after a cumulative rainfall $\left(\mathrm{P}_{\text {cum }}\right)$ of $11 \mathrm{~mm}$ and progressively decreases with increasing $\mathrm{P}_{\text {cum. }}$. The results highlight the impacts and complexity of subsurface rock fragments on the production of runoff volume and soil loss and calls for attention in process-based runoff and erosion models.

KEYWORDS: surface sealing, stony soils, rainfall simulation, laboratory experiments

\section{Introduction}

The effect of rock fragments (i.e. mineral particles of $2 \mathrm{~mm}$ or larger in diameter) on hydraulic processes, runoff production and soil loss has been widely studied in the last decades both on agricultural and non-agricultural soils with natural and simulated rainfall events in field and laboratory conditions (e.g. Katra et al., 2008; Poesen et al., 1994; Valentin and Casenave, 1992). Most of these experiments have only considered the effects of the visible rock fragments that are resting on the soil surface or that are partially embedded in the topsoil, without paying too much attention to the amount, size and depth of the subsurface rock fragments (e.g. Cerdà, 2001; Mayor et al., 2009; Poesen et al., 1998; Zavala et al., 2010). Agricultural soils containing rock fragments are globally widespread and occur under different environmental conditions and land use types (i.e. cropland, rangeland and fallow). Especially in semi-arid and arid environments, hillslopes are often characterised by poorly vegetated soils covered with rock fragments. For example in the Mediterranean, soils containing significant amounts of rock fragments occupy more than $60 \%$ of the land (Poesen and Lavee, 1994). A high rock fragment cover is common on these soils (e.g. $25 \%$ on average in cultivated and abandoned fields, López-Vicente and Navas, 2009), and in soils developed on recent geological materials, such as young volcanic islands (Asio et al., 2006), alluvial, colluvial or glacial deposits. Field and laboratory studies have indicated that rock fragments in the topsoil can have a large impact on soil properties, soil quality, hydraulic, hydrological and erosion processes (e.g. de Figueiredo and Poesen, 1998; Mayor et al., 2009; Poesen and Lavee, 1994; Poesen et al., 1994; Urbanek and Shakesby, 2009; Soto and Navas, 2004; van Wesemael et al., 1995; Zavala et al., 2010) (Table 1). During a rainfall event, rock fragments resting on the soil surface protect the soil from raindrop impact and soil detachment due to splash, they reduce the physical degradation (i.e. surface sealing and compaction) of the soil surface and increase 
infiltration rates (Poesen et al., 1990; Renard et al., 1997), and they affect overland flow velocity, detachment and transport capacity of the overland flow (Guo et al., 2010). For a review on the impacts of rock fragments on soil properties, hydrological processes, physical soil degradation, soil erosion and soil productivity we refer to Poesen and Lavee (1994) and Poesen et al. (1994) (Table 1).

Due to the widespread occurrence of soils containing rock fragments and their potential impact on hydrological and soil erosion processes, controlled field and laboratory studies have been conducted to investigate the most important rock fragment properties affecting these processes. Although rock fragment cover at the soil surface is considered to be the most important rock fragment property affecting hydrological and soil erosion processes, several studies have indicated that other rock fragment properties (e.g. size, shape and position in the topsoil) could also have a significant effect (de Figueiredo and Poesen, 1998; Guo et al., 2010; Katra et al., 2008; Poesen and Ingelmo-Sanchez, 1992; Poesen and Lavee, 1991; Valentin, 1994). Rock fragments are usually not randomly distributed within the soil profile. It is well known that often a considerable amount of rock fragments is incorporated in the topsoil and arable layer and is not visible at the soil surface. Rock fragment pavements are common in degraded soils where fine particles have been eroded from the topsoil due to interrill erosion processes (e.g. Zavala and Jordán, 2008). Tillage of dry stony soils with tine-like tools induces kinetic sieving resulting in an upward movement and concentration of large rock fragments in the topsoil (Oostwoud Wijdenes et al., 1997). Some studies have indicated that the vertical position of rock fragments in the topsoil (i.e. on top and embedded in the soil surface) can significantly influence the runoff and erosion-reducing effectiveness of rock fragments (e.g. Poesen, 1986; Poesen et al., 1990; Urbanek and Shakesby, 2009). Rainfall experiments have shown that surface sealing intensity is reduced when rock fragments are placed on top of the soil surface compared to rock fragments which are embedded in the topsoil (Katra et al., 2008; Mayor et al., 2009; Poesen, 1986; Poesen et al., 1990; Valentin, 1994). Well-embedded rock fragments in the topsoil can increase runoff and sediment yield, while rock fragments resting on top of the soil surface lead to a decrease in runoff and soil loss rates (Poesen and IngelmoSanchez, 1992). In all these studies, the investigated rock fragments still remain visible at the soil surface and only properties of these visible rock fragments (e.g. cover, position) are used for predictions in runoff and soil loss. However, there are indications that rock fragments completely incorporated in the topsoil (i.e. not visible at the soil surface) could have a significant influence on the percolation and water distribution in stony soils and therefore, also on infiltration, runoff and soil loss rates (Cousin et al., 2003; Rieke-Zapp et al., 2007; Urbanek 
and Shakesby, 2009). Similar to subsurface rock fragments, studies on vegetation cover also pointed to the importance of below-ground biomass on runoff and soil erosion rates (e.g. De Baets et al., 2006; Gyssels et al., 2005). Herrick et al. (2010) and Zavala et al. (2010) pointed to the need for further research, in the form of controlled experiments, in order to increase our understanding of the influence of stony soils on hydrological and erosion processes and to improve soil erosion predictions.

Therefore, this study was conducted to investigate whether subsurface rock fragments in topsoils (i.e. not visible at the soil surface) could significantly influence surface sealing, infiltration, runoff and soil erosion rates. It is hypothesised that these effects will most likely depend on the depth of the rock fragments below the soil surface, on the rock fragment size and, on the duration of the rain event.

\section{Materials and Methods}

\section{Experimental design}

\section{Interrill erosion plot}

All experiments were conducted in the laboratory, using a rectangular interrill erosion flume, $1.25 \mathrm{~m}$ x $1.78 \mathrm{~m}$ (Poesen et al., 1990; Smets and Poesen, 2009; Smets et al., 2007) (Fig. 1). The erosion flume has a central test area of $0.60 \times 0.94 \mathrm{~m}$ with a total depth of $0.15 \mathrm{~m}$. The test area is surrounded by a buffer area of $0.30 \mathrm{~m}$ wide, and both areas are identically treated in order to compensate for losses of water and sediment due to splash from the central test area. On the bottom of the erosion flume, wet floor cloths are placed on top of perforated plates to avoid losses of soil by percolation. Sediment-laden runoff from the test area was collected at the downslope end of the erosion flume. Because the edges of the test area are ca. $1.0 \mathrm{~cm}$ higher than the soil surface of the buffer area, the collected runoff and sediment only originate from the test area. Experiments were conducted on a medium slope gradient, i.e. $15 \%\left(8.5^{\circ}\right)$.

\section{Soil sampling}

The soil used in the experiments was a silt loam topsoil (Luvisol, FAO et al., 1998) sampled in central Belgium $\left(50^{\circ} 52^{\prime} 12^{\prime}{ }^{\prime} \mathrm{N}, 4^{\circ} 39^{\prime} 01^{\prime \prime} \mathrm{E}\right)$ at a depth of 0-30 $\mathrm{cm}$ from former cropland. The soil has $12 \%$ clay $(<0.002 \mathrm{~mm}), 80 \%$ silt $(0.002-0.063 \mathrm{~mm})$ and $8 \%$ sand $(0.063-2 \mathrm{~mm})$ and $1.9 \%$ soil organic matter, determined using conventional sieve-pipette and titration methods, respectively. Prior to each experiment, the soil was air-dried (at room temperature, ca. $20{ }^{\circ} \mathrm{C}$ ), for 4 days resulting in an initial gravimetric moisture content of $13.4 \% \pm 0.9$. Next, soil clods 
were destroyed to pass through a sieve with circular holes of $1.2 \mathrm{~cm}$ diameter in order to simulate a fine seedbed.

\section{Simulated rainfall}

Rainfall was simulated during $60 \mathrm{~min}$ by a single-nozzle, continuous-spray system (Poesen and Lavee, 1991; Smets and Poesen, 2009). Experiments were conducted with a water pressure of $0.33 \mathrm{bar}$ at the nozzle outlet, yielding a mean rainfall intensity over the test area of $67 \mathrm{~mm} \mathrm{~h}^{-1}$. Because fall-height equalled $3.25 \mathrm{~m}$, and using the drop-size distribution and the calculated drop-fall velocity (Laws, 1941), the simulated rainfall produced a kinetic energy at the soil surface of $15.2 \mathrm{~J} \mathrm{~m}^{-2} \mathrm{~mm}^{-1}$. This equals to ca. $60 \%$ of the energy of natural rainfall with similar intensities (Salles et al., 2002). Such a high rainfall intensity was chosen as it is usually during high rainfall intensities that large volumes of runoff and soil loss occur. As to the frequency of such a rainfall event, Casas et al. (2004) indicated that for a rainfall station in Barcelona (northeast Spain) the return period ranges from less than 1 year to 2-5 years up to 50 years for a corresponding rainfall duration of 10, 30 and 60 minutes, respectively.

\section{Rock fragments}

Two types of rock fragments were used in the experiments, each type having a different mean rock fragment size (RFS). The marble fragments, originating from China and classified as rounded, had a mean largest diameter of $0.04 \mathrm{~m} \pm 0.01$. The shale fragments, collected in southern Belgium and classified as sub-angular, had a mean largest diameter of $0.20 \mathrm{~m} \pm 0.02$ (mean thickness equals $0.02 \mathrm{~m}$ ). These two types of rock fragments were selected in order to represent two contrasting rock fragment sizes and shapes, as may be found in cultivated soils (Poesen et al., 1998).

Four different vertical subsurface positions of the rock fragments in the bare soil top layer were simulated, i.e. rock fragments incorporated in the topsoil at a depth of $0.001,0.01$, 0.05 and $0.10 \mathrm{~m}$ below the soil surface (Fig. 2). For each vertical position, the rock fragments were applied at a cover level of $60 \%$. In addition control experiments with bare soil surfaces, without rock fragments incorporated in the topsoil (control), were conducted as well.

\section{Experimental procedure}

In order to simulate the subsurface positions of rock fragments in the topsoil, the soil in the interrill erosion flume, set at the desired slope angle (15\%), was applied in different layers. Initially, the erosion flume was filled with the sieved, air-dried soil to a depth of $0.03,0.08$, 
0.0120 or $0.0129 \mathrm{~m}$, depending on the vertical position of the rock fragments simulated. Next, the rock fragments were randomly applied at the desired cover level $(60 \%)$ and covered with a second layer of soil up to the surface of the erosion plot, i.e., to a total depth of $0.15 \mathrm{~m}$, simulating a cultivated topsoil. The soil surface was flattened using a shelf. This resulted in a dry bulk density of the fine earth of $1.20 \mathrm{~kg} \mathrm{~m}^{-3} \pm 0.04$, and a maximum clod roughness height of ca. $0.01 \mathrm{~m}$ (Fig. 3). In doing so, the simulated depth of the top of the rock fragments was $0.001,0.01,0.05$ or $0.10 \mathrm{~m}$. The total soil depth in the erosion plot (i.e. $0.15 \mathrm{~m}$ ) was sufficient for preventing the moist front to reach the bottom of the plot after a rainfall event of 60 minutes with an intensity of $67 \mathrm{~mm} \mathrm{~h}^{-1}$.

Before the start of each experiment, soil samples in the buffer area were taken to determine initial gravimetric soil moisture (\%) and bulk density $\left(\mathrm{kg} \mathrm{m}^{-3}\right)$. Rainfall intensity $\left(\mathrm{mm} \mathrm{h}^{-1}\right)$ over the test area was measured before and after each experiment during 3 min using a rain-gauge. Each experiment lasted for $60 \mathrm{~min}$, which was sufficient to reach steady-state conditions. During the experiments, runoff samples including sediment were taken during 1 min with an interval of $3 \mathrm{~min}$. The runoff samples were oven-dried at $105^{\circ} \mathrm{C}$ during $24 \mathrm{~h}$. For each combination of vertical subsurface position and RFS, three to four replicate experiments were conducted and four replicates were conducted for the control treatment. In total, 32 rainfall experiments were conducted (Table 2).

\section{Data processing}

Interrill soil loss (ISL, $\mathrm{kg} \mathrm{m}^{-2}$ ) was determined by weighing the oven-dried runoff samples. Runoff depth (mm) was calculated after subtracting the mass of the ISL from the mass of the runoff samples. Total interrill soil loss (total ISL, $\mathrm{kg} \mathrm{m}^{-2}$ ) for each experiment was calculated by integrating the ISL samples over the duration of each experiment (60 minutes). Because rainfall intensity was kept constant during the experiments as well as antecedent soil moisture, infiltration rate $\left(\mathrm{mm} \mathrm{h}^{-1}\right)$ was calculated by subtracting the runoff rate (calculated using the runoff volume and the sampling period), from the rainfall intensity. Surface sealing intensity was assessed indirectly, i.e. through its effects on infiltration rates. The evolution of infiltration rates is a measure for the surface sealing intensity.

Analysis of variance (ANOVA) was conducted using the SAS Enterprise Guide statistical programme (version 4.1., 2006) in order to analyse the significance of subsurface position and of RFS on the effectiveness of rock fragments in reducing runoff and interrill erosion rates. 


\section{Results}

\section{Effects of subsurface rock fragments on infiltration rates and runoff volume}

The evolution of the mean infiltration rates for all tested treatments during a simulated rain event is shown in Fig. 4.

Differences in infiltration rates between the tested vertical positions of the rock fragments below the soil surface is highest during the first 10 minutes of the rainfall experiment and decreases over time. The final infiltration rates after 60 minutes of simulated rainfall for all experimental treatments (different RFS and depths below the soil surface) range between 17 and $21 \mathrm{~mm} \mathrm{~h}^{-1}$. Since infiltration rates are calculated from the measured runoff rates and the constant rainfall intensity, statistical differences between the tested experimental treatments are calculated and discussed for the runoff volumes.

In order to produce results representative for the natural conditions and valuable for soil conservation and management practices, the cumulative effect of the different experimental treatments is analysed for three time intervals, i.e. from 0 to 10 minutes (cumulative rainfall, $\mathrm{P}_{\text {cum }}$, equals $\left.11 \mathrm{~mm}\right)$, from 0 to 30 minutes $\left(\mathrm{P}_{\text {cum }}=33 \mathrm{~mm}\right)$ and from 0 to 60 minutes $\left(\mathrm{P}_{\text {cum }}=67\right.$ $\mathrm{mm})$. Mean total runoff volumes after $\mathrm{P}_{\text {cum }}$ of 11,33 and $67 \mathrm{~mm}$ for the control experiment and for all experiments with subsurface rock fragments are given in Table 3. For rock fragments at a depth of $0.001 \mathrm{~m}$ below the soil surface, total runoff volume is larger compared to the control experiment for both rock fragment sizes $(\mathrm{RFS}=0.04$ and $0.20 \mathrm{~m}$ ) and for the three time intervals $\left(\mathrm{P}_{\text {cum }}=11,33\right.$ and $\left.67 \mathrm{~mm}\right)$. Furthermore, higher values of total runoff volume are obtained after the first time interval $\left(\mathrm{P}_{\text {cum }}=11 \mathrm{~mm}\right)$ for rock fragments $(\mathrm{RFS}=0.04 \mathrm{~m})$ at 0.01 , 0.05 and $0.10 \mathrm{~m}$ depth. Though the difference in total runoff volume for the treatments tested decreases progressively over time to similar values as those for the control experiment $\left(\mathrm{P}_{\text {cum }}=\right.$ $33 \mathrm{~mm}$ ) and even to lower values at the end of the rainfall simulation $\left(\mathrm{P}_{\text {cum }}=67 \mathrm{~mm}\right)$. However, the differences in total runoff volume and thus water infiltration between the different treatments and the control experiment are not significant (at the 5\% level) for each time interval, except for the experiment with RFS $=0.04 \mathrm{~m}$ at a depth of $0.10 \mathrm{~m}$ after $11 \mathrm{~mm}$ of rainfall.

Relative total runoff volumes, compared to the control experiment, for all treatments with subsurface rock fragments are calculated for each time interval $\left(\mathrm{P}_{\text {cum }}=11,33\right.$ and $\left.67 \mathrm{~mm}\right)$ and plotted in Fig. 5. This analysis indicates that the variability of the relative total runoff volume decreases with an increasing cumulative rainfall depth. Although not significant at the $5 \%$ level, differences in runoff volume appear during the first $11 \mathrm{~mm}$ of cumulative rainfall, with the highest relative runoff volume (compared to the control experiment) for the 
experiments with the small rock fragments $(\mathrm{RFS}=0.04 \mathrm{~m})$ applied at a depth of 0.05 and 0.10 $\mathrm{m}$ below the soil surface. In contrast, the lowest relative runoff volume is observed for the large rock fragments $(\mathrm{RFS}=0.20 \mathrm{~m})$ at the same depths below the soil surface.

\section{Effects of subsurface rock fragments on interrill soil loss}

The evolution of the mean interrill soil loss rates (ISL) for all tested treatments is shown in Fig. 6. It is clear that a larger variation in ISL is observed for all experiments compared to the variations in infiltration and runoff rates. The highest ISL values are observed in experiments with rock fragments $(\mathrm{RFS}=0.04$ and $0.20 \mathrm{~m}$ ) applied at a depth of $0.001 \mathrm{~m}$ below the soil surface. Mean total interrill soil loss after 11, 33 and $67 \mathrm{~mm}$ of cumulative rainfall for the control experiment and for all experiments with subsurface rock fragments are given in Table 3 , including the results from the statistical difference test (at the 5\% level). Although there is a high variation in total ISL, only for two treatments (i.e. $P_{\text {cum }}=33 \mathrm{~mm}$, RFS $=0.04 \mathrm{~m}$, depth $=$ $0.10 \mathrm{~m}$ and; $P_{\text {cum }}=33 \mathrm{~mm}$, RFS $=0.20 \mathrm{~m}$, depth $=0.05 \mathrm{~m}$ ) total ISL is significantly different from the total ISL observed during the control experiment. Relative total ISL, compared to the control experiment, for all treatments with subsurface rock fragments are calculated for each time interval $\left(\mathrm{P}_{\text {cum }}=11,33\right.$ and $\left.67 \mathrm{~mm}\right)$ and plotted in Fig. 7. The variation of relative ISL for the control experiment over the four replicates decreases significantly with an increasing cumulative rainfall, i.e. from 11 to 33 and $67 \mathrm{~mm}$ (indicated by the width of the shaded area in Fig. 8). In general, relative total ISL decreases with an increasing depth of subsurface rock fragments below the soil surface for all time intervals. After a rainfall event of 33 and $67 \mathrm{~mm}$ $\mathrm{P}_{\text {cum }}$, higher values of total ISL, compared to the bare soil experiment, are observed for the rock fragments applied at $0.001,0.01$ and $0.05 \mathrm{~m}$ depth and at 0.001 and $0.01 \mathrm{~m}$ depth below the soil surface for the rock fragments with small $(\mathrm{RFS}=0.04 \mathrm{~m})$ and large $(\mathrm{RFS}=0.20 \mathrm{~m})$ rock fragment sizes, respectively (Table 3 ).

\section{Discussion}

The results of this study indicate that subsurface rock fragments have a larger impact on total interrill soil loss than on total runoff volume, i.e. the differences between rock fragment treatments and the control experiments are higher for total ISL. Although only very small differences in total runoff volume are observed between all rock fragment treatments, total ISL is relatively more affected. This observation is explained with a conceptual model in Fig. 8. At the start of each simulated rainfall experiment, the soil surface of the interrill area was completely bare. Therefore, the simulated rainfall directly impacted on the soil surface. 
Eventually, all rainfall infiltrates in the soil surface and due to surface seal formation, the infiltration rate gradually decreases and runoff rate increases until a steady-state condition is reached. This process is similar for both the control and the rock fragment treatments and therefore, only small differences in infiltration and runoff rates are observed. When rock fragments are present below the soil surface, the soil moisture content in the areas between the top of the rock fragments and the soil surface will increase faster (leading to more rapid ponding) compared to the areas where no rock fragments are present because of the presence of an impeding object (subsurface rock fragments). These areas of higher soil moisture content are saturated faster, leading to a decrease in soil cohesion and a rapid increase in soil detachability (Poesen, 1981). Due to this decrease in soil cohesion in the topsoil above the rock fragments, soil particles are easily detached and transported by the runoff (Fig. 8). Therefore, for similar runoff volumes, higher total ISL is observed in general with rock fragments incorporated below the soil surface compared to a topsoil without subsurface rock fragments. Since the areas of increased saturation and decreased soil cohesion are less fragmented for the large rock fragments $(\mathrm{RFS}=0.20 \mathrm{~m})$ compared to the small rock fragments $(\mathrm{RFS}=0.04 \mathrm{~m})$, higher total ISL is observed for the large rock fragments just below the soil surface (depth = $0.001 \mathrm{~m})$.

Similar observations were made for mulch covers and geotextiles (Smets et al., 2008; Smets et al., 2007), i.e. a larger impact of these soil surface covers is observed on total ISL than on total runoff volumes. According to these authors, an increase in mulch or geotextile surface cover has several cumulative impacts on soil erosion process compared to runoff process. The processes described above are observed for runoff and interrill soil loss only. However, once runoff starts to incise in the topsoil and rills are developing, other processes will become important (Poesen et al., 1999). Although Govers and Poesen (1988) indicated that for an entire bare field plot $\left(7500 \mathrm{~m}^{2}\right)$ rill (and gully) erosion is more important than interrill erosion, the relative importance of interrill erosion varies in time and space. Therefore, depending on the interrill surface characteristics, interrill soil erosion processes could have a significant contribution to total soil loss and should be taken into account in erosion models.

In order to improve predictions of runoff and soil erosion rates, the effects of rock fragments are incorporated in several soil erosion models (e.g. ANSWERS, Amin and Ahmadi, 2006; RMMF model, Morgan, 2001; EUROSEM, Morgan et al., 1998; RUSLE, Renard et al., 1997). In these soil erosion models, only rock fragment cover is used as a parameter to represent the effects of rock fragments in topsoils. These models assume that only rock fragments which are visible at the soil surface will directly contribute to interrill soil erosion 
rates. The results of this study highlight the impacts and complexity of subsurface rock fragments below the soil surface on the production of runoff volume and especially on soil loss. Therefore, attention is required when using runoff and erosion models to predict the impacts of soils containing subsurface rock fragments on runoff and interrill soil erosion rates. One way forward could be the adjustment of the soil erodibility factors in these models to the vertical position and size of subsurface rock fragments in the topsoil.

\section{Conclusions}

In this study it is hypothesised that subsurface rock fragments (i.e. fragments not visible at the soil surface) could influence surface sealing, infiltration, runoff and interrill soil erosion rates and that these effects depend on the depth of the rock fragments below the soil surface, on the rock fragment size and on the duration of the rain event. By conducting rainfall simulations on an interrill erosion flume with a simulated cultivated topsoil, this study indicates that surface sealing, infiltration rates and runoff volumes are affected but not significantly by subsurface rock fragments incorporated at different depths below the soil surface. However, for both contrasting rock fragments sizes (i.e. mean largest diameter of 0.04 and $0.20 \mathrm{~m}$ ) considerable differences in total interrill soil loss are observed after 11, 33 and $67 \mathrm{~mm}$ of cumulative rainfall. These observations are explained by a more rapid increase in soil moisture content in the areas above the subsurface rock fragments, leading to a decrease in soil cohesion and a rapid increase in soil detachability compared to a topsoil without subsurface rock fragments (control). For a similar runoff volume, more sediment is then transported by interrill flow on topsoils with subsurface rock fragments compared to the control experiment.

The observed variation in runoff volume and interrill soil loss between all the tested treatments varies with cumulative rainfall depth. The results of this study highlight the impacts and complexity of subsurface rock fragments below the soil surface on the production of runoff volume and soil loss and calls for attention in process-based runoff and erosion models.

\section{References}

Abrahams AD, Parsons AJ. 1991. Relation between infiltration and stone cover on a semiarid hillslope, southern Arizona. Journal of Hydrology 122: 49-59.

Amin S, Ahmadi SH. 2006. Incorporating rock fragments in soil erosion models: a case study, the ANSWERS model. Iranian Journal of Science \& Technology, Transaction B, Engineering 30: B4. 
Asio VB, Cabunos CC, Chen ZS. 2006. Morphology, physiochemical characteristics, and fertility of soils from quaternary limestone in Leyte, Philippines. Soil Science 171(8): 648-661.

Casas MC, Codina B, Redaño A, Lorente J. 2004. A methodology to classify extreme rainfall events in the western Mediterranean area. Theoretical and Applied Climatology 77:139-150.

Cerdà A. 2001. Effects of rock fragment cover on soil infiltration, interrill runoff and erosion. European Journal of Soil Science 52: 59-68.

Cousin I, Nicoullaud B, Coutadeur C. 2003. Influence of rock fragments on the water retention and water percolation in a calcareous soil. Catena 53: 97-114.

De Baets S, Poesen J, Gyssels G, Knapen A. 2006. Effects of grass roots on the erodibility of topsoils during concentrated flow. Geomorphology 76: 54-67.

De Figueiredo T, Poesen J. 1998. Effects of surface rock fragment characteristics on interrill runoff and erosion of a silty loam soil. Soil \& Tillage Research 46: 81-95.

Decock K. 1991. Invloed van de stenige bedekkingsgraad en de steenpositie op de hydrologie en de erosie van lemige intergeulgebieden: laboratoriumexperimenten. M.Sc. Thesis, Faculty of Science, Catholic University of Leuven, Belgium. 94 pp.

FAO, ISRIC, ISSS. 1998. World Reference Base for Soil Resources. World Soil Resources Report 84. FAO, Rome, pp. 88.

Foster GR, Flanagan DC, Nearing MA, Lane LJ, Risse LM, Finkner SC. 1995. Water Erosion Prediction Project $(W E P P)$. Technical documentation. NSERL Report No. 10. National Soil Erosion Research Laboratory. USDA-ARS. West Lafayette, IN 47907-1196.

Govers G, Poesen J. 1988. Assessment of the interrill and rill contributions to total soil lossfrom an upland field plot. Geomorphology 4: 343-354.

Guo T, Wang Q, Li D, Zhuang J. 2010. Effect of surface Stone cover on sediment and solute transport on the slope of fallow land in the semi-arid loess region of Northwestern China. Journal of Soils and Sediments 10: 1200-1208.

Gyssels G, Poesen J, Bochet E, Li Y. 2005. Impact of plant roots on the resistance of soils to erosion by water: a review. Progress in Physical Geography 29: 189-217.

Herrick JE, Van Zee JW, Belnap J, Johansen JR, Remmenga M. 2010. Fine gravel controls hydrologic and erodibility responses to trampling disturbance for coarse-textured soils with weak cyanobacterial crusts. Catena 83: 119-126.

Jii-Shuh Jean, Koe-Fe Ai, Kaimin Shih, Chao-Chi Hung. 2000. Stone cover and slope factors influencing hillside surface runoff and infiltration: laboratory investigation. Hydrological Processes 14: 1829-1849.

Katra I, Lavee H, Sarah P. 2008. The effect of rock fragment size and position on topsoil moisture on arid and semi-arid hillslopes. Catena 72: 49-55.

Laws J. 1941. Measurements of the fall-velocity of waterdrops and raindrops. Transactions, Geophysical Union 22: 709-721. 
Loosvelt L. 2007. Scale dependent influence of rock fragment cover on soil infiltration, runoff and sediment yield in arid zones of Chie. M.Sc. Thesis. Faculty of Bioscience Engineering, Ghent University, Belgium. 155 pp.

López-Vicente M, Navas A. 2009. Predicting soil erosion with RUSLE in Mediterranean agricultural systems at catchment scale. Soil Science 174(5): 272-282.

Mandal UK, Rao KV, Mishra PK, Vittal KPR, Sharma KL, Narsimlu B, Venkanna K. 2005. Soil infiltration, runoff and sediment yield from a shallow soil with varied stone cover and intensity of rain. European Journal of Soil Science 56: 435-443.

Mayor AG, Bautista S, Bellot J. 2009. Factors and interactions controlling infiltration, runoff, and soil loss at the microscale in a patchy Mediterranean semiarid landscape. Earth Surface Processes and Landforms 34: 17021711.

Morgan RPC. 2001. A simple approach to soil loss prediction: a revised Morgan-Morgan-Finney model. Catena 44: $305-322$.

Morgan RPC, Quinton JN, Smith RE, Govers G, Poesen JWA, Auerswald K, Chisci G, Torri D, Styczen ME. 1998. The European soil erosion model (EUROSEM): a dynamic approach for predicting sediment transport from fields and small catchments. Earth Surface Processes and Landforms 23: 527-544.

Oostwoud Wijdenes D, Poesen J, Vandekerckhove L, de Luna E. 1997. Chiselling effects on the vertical distribution of rock fragments in the tilled layer of a Mediterranean soil. Soil \& Tillage Research 44: 55-66.

Poesen J. 1986. Surface sealing as influenced by slope angle and position of simulated stones in the top layer of loose sediments. Earth Surface Processes and Landforms 11: 1-10.

Poesen J. 1981. Rainwash experiments on the erodibility of loose sediments. Earth Surface Processes and Landforms 6: 285-307.

Poesen J, de Luna E, Franca A, Nachtergaele J, Govers G. 1999. Concentrated flow erosion rates as affected by rock fragment cover and initial soil moisture content. Catena 36: 315-329.

Poesen J, Ingelmo-Sanchez F. 1992. Runoff and sediment yield from topsoils with different porosity as affected by rock fragment cover and position. Catena 19: 451-474.

Poesen J, Ingelmo-Sanchez F, Mücher H. 1990. The hydrological response of soil surfaces to rainfall as affected by cover and deposition of rock fragments in the top layer. Earth Surface Processes and Landforms 15: 653671.

Poesen J, Lavee H. 1991. Effects of size and incorporation of synthetic mulch on runoff and sediment yield from interrills in a laboratory study with simulated rainfall. Soil \& Tillage Research 21: 209-223.

Poesen J, Lavee H. 1994. Rock fragments in top soils: significance and processes. Catena 23: 1-28.

Poesen J, Torri D, Bunte K. 1994. Effects of rock fragments on soil erosion by water at different spatial scales: a review. Catena 23: 141-166.

Poesen J, van Wesemael B, Bunte K, Solé Benet A. 1998. Variation of rock fragment cover and size along semiarid hillslopes: a case-study from southeast Spain. Geomorphology 23: 323-335. 
Renard KG, Foster GR, Weesies DK, McCool DK, Yoder DC. 1997. Predicting soil erosion by water: A Guide to Conservation Planning with the Revised Universal Soil Loss Equation (RUSLE). Handbook \#703. US Department of Agriculture, Washington D.C.

Rieke-Zapp D, Poesen J, Nearing MA. 2007. Effects of rock fragments incorporated in the soil matrix on concentrated flow hydraulics and erosion. Earth Surface Processes and Landforms 32: 1063-1076.

Salles C, Poesen J, Sempere-Torres D. 2002. Kinetic energy of rain and its functional relationship with intensity. Journal of Hydrology 257: 256-270.

Sepaskhah AR, Amin S, Estakhri R. 2004. Watershed sediment yield prediction for soils containing rock fragments. Iranian Journal of Science \& Technology, Transaction B, Engineering 28: B1.

Smets T, Poesen J. 2009. Impacts of soil tilth on the effectiveness of biological geotextiles in reducing runoff and interrill erosion. Soil \& Tillage Research 103: 356-363.

Smets T, Poesen J, Bochet E. 2008. Impact of plot length on the effectiveness of different soil-surface covers in reducing runoff and soil loss by water. Progress in Physical Geography 32: 654-677.

Smets T, Poesen J, Fullen MA, Booth CA. 2007. Effectiveness of palm and simulated geotextiles in reducing runoff and inter-rill erosion on medium and steep slopes. Soil Use and Management 23: 306-316.

Soto J, Navas A. 2004. A model of ${ }^{137} \mathrm{Cs}$ activity profile for soil erosion studies in uncultivated soils of Mediterranean environments. Journal of Arid Environments 59: 719-730.

Urbanek E, Shakesby RA. 2009. Impact of stone content on water movement in water-repellent sand. European Journal of Soil Science 60: 412-419.

Valentin C. 1994. Surface sealing as affected by various rock fragment covers in West Africa. Catena 23: 87-97.

Valentin C, Casenave A. 1992. Infiltration into sealed soils as influenced by gravel cover. Soil Science Society of America Journal 56: 1667-1673.

Van Schaik L. 2010. The role of macropore flow from plot to catchment scale: a study in a semi-arid area. Ph.D. Thesis, Faculteit Geowetenschappen, Universiteit Utrecht, The Netherlands, 174 pp.

van Wesemael B, Poesen J, de Figueiredo T. 1995. Effects of rock fragments on physical degradation of cultivated soils by rainfall. Soil \& Tillage Research 33: 229-250.

Xiao-Yan Li. 2003. Gravel-sand mulch for soil and water conservation in the semiarid loess region of northwest China. Catena 52: 105-127.

Zavala LM, Jordán A. 2008. Effect of rock fragment cover on interrill soil erosion from bare soils in Western Andalusia, Spain. Soil Use and Management 24: 108-117.

Zavala LM, Jordán A, Bellinfante N, Gil J. 2010. Relationships between rock fragment cover and soil hydrological response in a Mediterranean environment. Soil Science and Plant Nutrition 56: 95-104. 
Table I. Summary of studies investigating the effects of surface, embedded and subsurface rock fragments on hydrological and erosion processes. Position of rock fragments (RF) in the topsoil (A): RF resting on the soil surface, (B) RF well embedded in the top layer and, (C) RF completely incorporated in the topsoil (subsurface RF). RFS: rock fragment size. RFC: rock fragment cover. Research method N: natural rainfall, RS: rainfall simulation

\begin{tabular}{|c|c|c|c|c|c|c|c|}
\hline Source & \multicolumn{3}{|c|}{$\begin{array}{l}\text { Position in } \\
\text { soil }\end{array}$} & Type of RF & $\begin{array}{l}\text { RFS } \\
(\mathrm{cm})\end{array}$ & $\begin{array}{l}\text { RFC } \\
(\%)\end{array}$ & $\begin{array}{l}\text { Research } \\
\text { Method }\end{array}$ \\
\hline Cerdà (2001) & $\mathrm{x}$ & & & - & $\geq 0.2$ & $50-98$ & Field, RS \\
\hline Guo et al. (2010) & $\mathrm{x}$ & & & - & $7.6,18.4$ & $0,5.1,20.8$ & Field, RS \\
\hline Jii-Shuh Jean et al. (2000) & $\mathrm{x}$ & & & - & $1.0-2.0$ & $10,20,30$ & $\mathrm{Lab}$ \\
\hline Xiao-Yan Li (2003) & $\mathrm{x}$ & & & Fluvial deposits & $0.3-4.0$ & $20-100$ & \\
\hline Zavala \& Jordan (2008) & $\mathrm{x}$ & & & - & $2-10$ & $3-85$ & Field, RS \\
\hline Zavala et al. (2010) & $\mathrm{x}$ & & & - & $0.2-10$ & $37-77$ & Field, RS \\
\hline Abrahams \& Parsons (1991) & $\mathrm{x}$ & $\mathrm{x}$ & & - & $\geq 0.5$ & $10-85$ & Field, RS \\
\hline $\begin{array}{l}\text { De Figueiredo \& Poesen } \\
\text { (1998) }\end{array}$ & $\mathrm{x}$ & $\mathrm{x}$ & & - & $2.0-4.8$ & $17-66$ & $\mathrm{Lab}$ \\
\hline Katra et al. (2008) & $\mathrm{x}$ & $\mathrm{x}$ & & - & $\begin{array}{l}5-7,8- \\
10\end{array}$ & - & Field, N \\
\hline Loosvelt (2007) & $\mathrm{x}$ & $\mathrm{x}$ & & - & - & $15-60$ & Field, RS \\
\hline Mayor et al. (2009) & $\mathrm{x}$ & $\mathrm{x}$ & & Limestone fragments & - & $6.0-16.3$ & Field, RS \\
\hline Poesen (1986) & $\mathrm{x}$ & $\mathrm{x}$ & & Glass marbles & 1.66 & 12 & $\mathrm{Lab}$ \\
\hline Poesen et al. (1990) & $\mathrm{x}$ & $\mathrm{x}$ & & Limestone fragments & 7.0 & $20,34,49,65,83$ & Lab \\
\hline Poesen et al. (1998) & $\mathrm{x}$ & $\mathrm{x}$ & & $\begin{array}{l}\text { Conglomerate, } \\
\text { micashist }\end{array}$ & $\geq 0.5$ & $0-70$ & Field, N \\
\hline Valentin (1994) & $\mathrm{x}$ & $\mathrm{x}$ & & - & $\geq 0.2$ & $\geq 10$ & Field, RS \\
\hline Valentin \& Casenave (1992) & $\mathrm{x}$ & $\mathrm{x}$ & & - & $0.2-15$ & $0-95$ & Field, RS \\
\hline Amin \& Ahmadi (2006) & $\mathrm{x}$ & $\mathrm{x}$ & $\mathrm{x}$ & - & $\geq 0.5$ & 12,25 & Field, N \\
\hline Cousin et al. (2003) & $\mathrm{x}$ & $\mathrm{x}$ & $\mathrm{x}$ & Limestone fragments & $\geq 0.2$ & 21-34 (vol.) & Field, N \\
\hline Herrick et al. (2010) & $\mathrm{x}$ & $\mathrm{x}$ & $\mathrm{x}$ & Gravel & - & $16.2-40.9$ & Field, RS \\
\hline Mandal et al. (2005) & $\mathrm{x}$ & $\mathrm{x}$ & $\mathrm{x}$ & - & $2.0-3.8$ & $3-65$ & Field, RS \\
\hline Poesen et al. (1999) & $\mathrm{x}$ & $\mathrm{x}$ & $\mathrm{x}$ & Flint pebbles & $0.5-1.0$ & $0-75$ & $\begin{array}{l}\text { Lab, conc. } \\
\text { flow }\end{array}$ \\
\hline Rieke-Zapp et al. (2007) & $\mathrm{x}$ & $\mathrm{x}$ & $\mathrm{x}$ & Fluvial deposits & $0.8,3.0$ & $\begin{array}{l}5,10,20,40 \\
\text { (vol.) }\end{array}$ & $\mathrm{Lab}$ \\
\hline Urbanek \& Shakesby (2009) & $\mathrm{x}$ & $\mathrm{x}$ & $\mathrm{x}$ & Slate fragments & $\begin{array}{l}1-3,4- \\
10\end{array}$ & $0-65$ (vol.) & $\mathrm{Lab}$ \\
\hline
\end{tabular}


Table II. Overview of interrill laboratory experiments

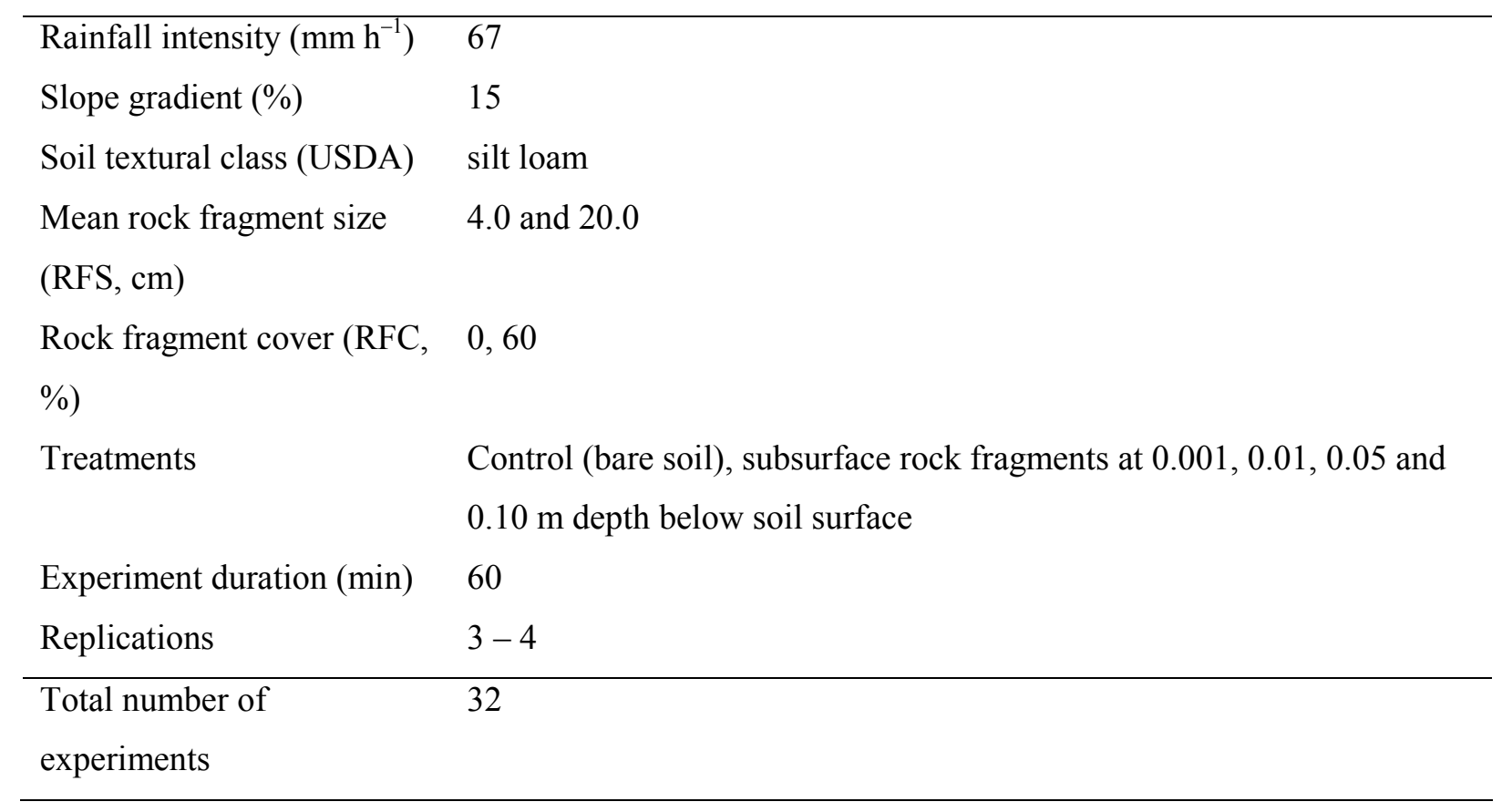

Table III. Mean values of cumulative runoff volume and total interrill soil loss (total ISL) for the different treatments and rock fragment sizes (RFS) obtained after 11, 33 and 67 of cumulative rainfall

\begin{tabular}{|c|c|c|c|c|c|c|c|}
\hline \multirow{2}{*}{\multicolumn{2}{|c|}{ Cumulative rainfall (mm) }} & \multicolumn{3}{|c|}{ Total runoff volume $(\mathrm{mm})$} & \multicolumn{3}{|c|}{ Total ISL $\left(\mathrm{kg} \mathrm{m}^{-2}\right)$} \\
\hline & & 11 & 33 & 67 & 11 & 33 & 67 \\
\hline & \multicolumn{7}{|c|}{ depth of rock } \\
\hline & \multicolumn{7}{|c|}{ fragments (m) } \\
\hline \multirow{4}{*}{$\mathrm{RFS}=4 \mathrm{~cm}$} & 0.001 & 4.2 & 20.4 & 43.3 & 0.06 & 0.43 & 0.95 \\
\hline & 0.01 & 3.8 & 19.1 & 41.2 & 0.08 & 0.42 & 0.87 \\
\hline & 0.05 & 3.9 & 19.5 & 41.9 & 0.06 & 0.37 & 0.72 \\
\hline & 0.10 & $5.3^{*}$ & 21.4 & 41.9 & 0.05 & $0.24 *$ & 0.59 \\
\hline \multirow[t]{4}{*}{$\mathrm{RFS}=20 \mathrm{~cm}$} & 0.001 & 4.2 & 20.7 & 43.6 & 0.08 & 0.51 & 1.07 \\
\hline & 0.01 & 3.6 & 19.7 & 42.9 & 0.06 & 0.36 & 0.85 \\
\hline & 0.05 & 3.1 & 18.8 & 41.9 & 0.05 & $0.22 *$ & 0.58 \\
\hline & 0.10 & 3.3 & 19.1 & 41.8 & 0.05 & 0.32 & 0.73 \\
\hline \multicolumn{2}{|l|}{ Control } & 3.7 & 19.4 & 42.3 & 0.07 & 0.33 & 0.74 \\
\hline
\end{tabular}

*Significantly different from the bare soil treatment at $\mathrm{p}<0.05$ 


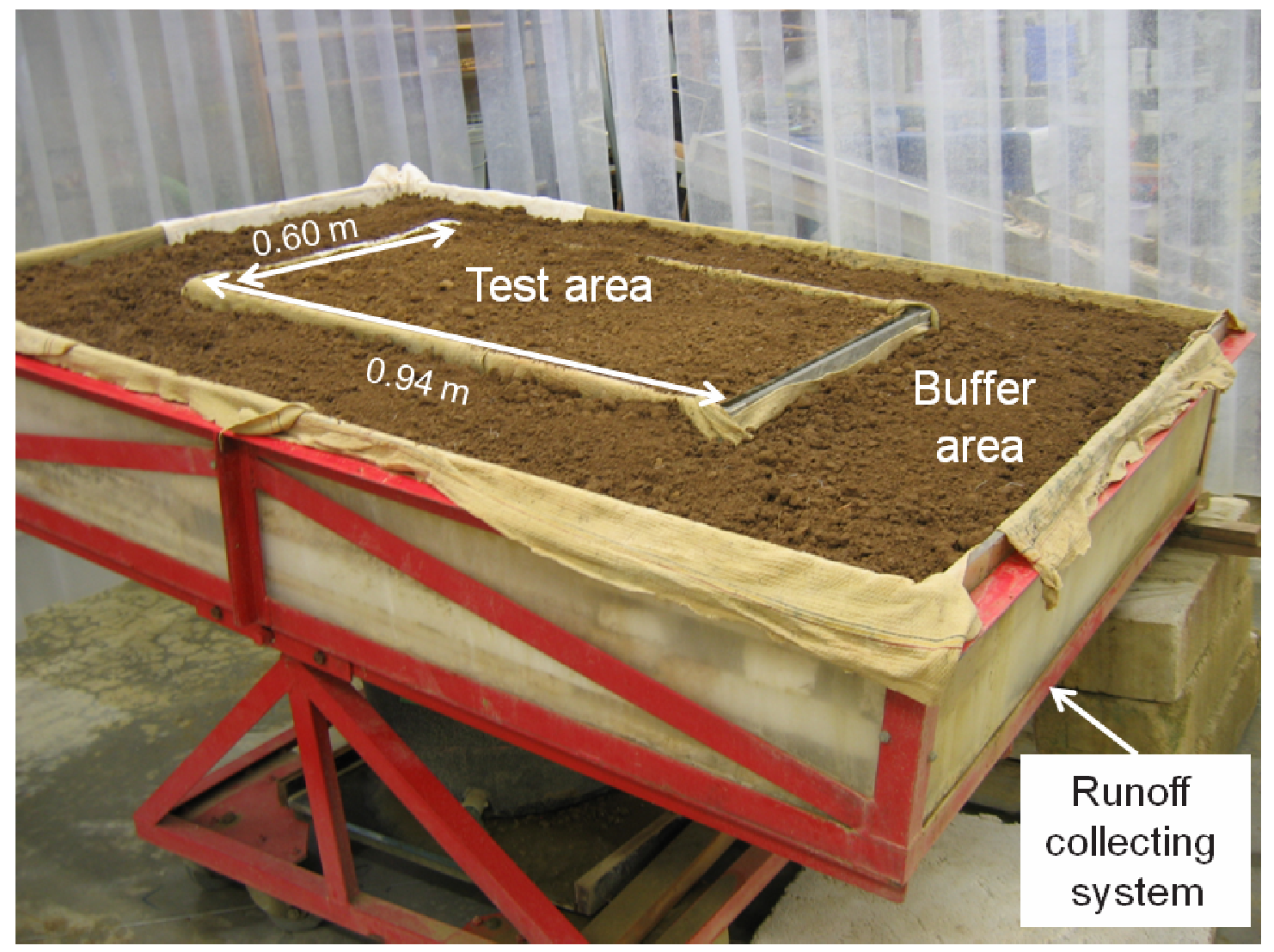

Figure 1. Interrill erosion flume used in this study. 


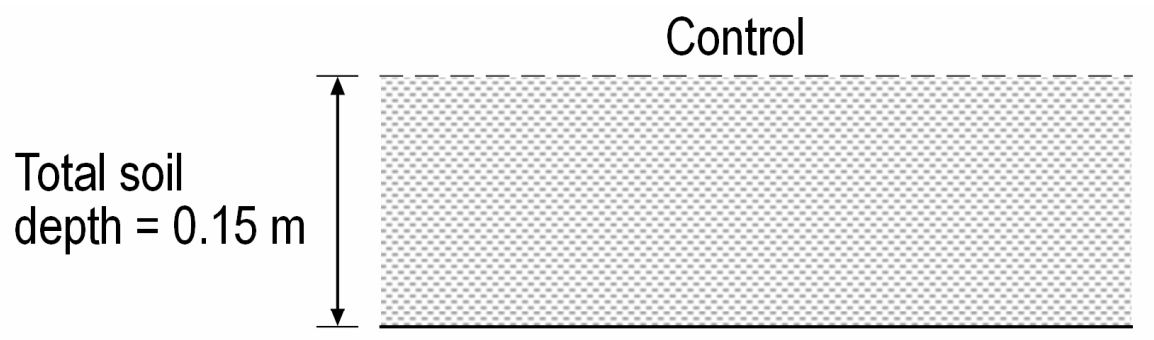

Depth $=0.001 \mathrm{~m}$
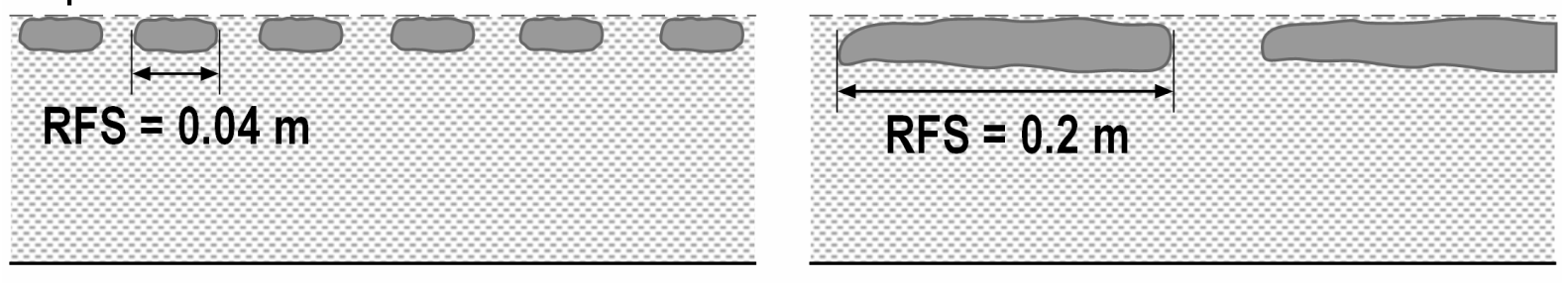

\section{Depth $=0.01 \mathrm{~m}$}
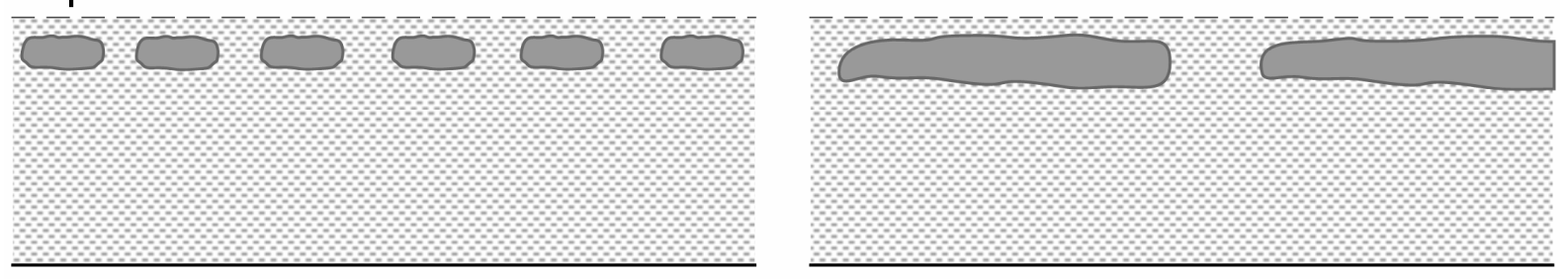

Depth $=0.05 \mathrm{~m}$
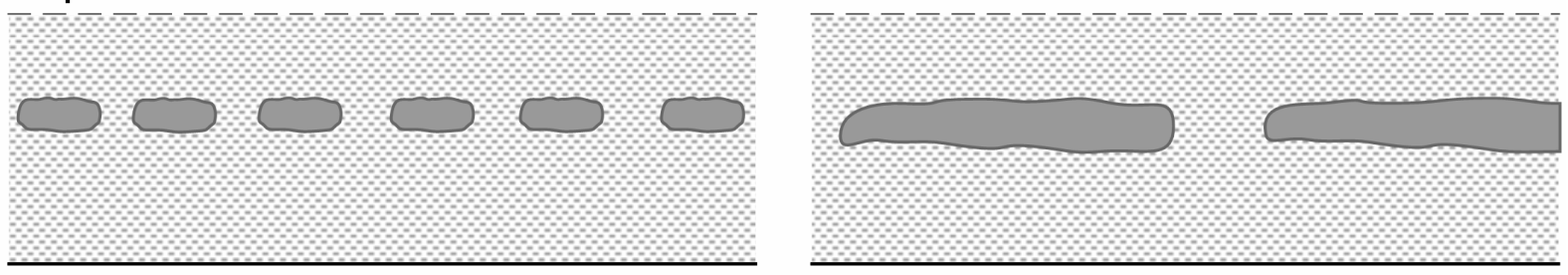

\section{Depth $=0.1 \mathrm{~m}$}
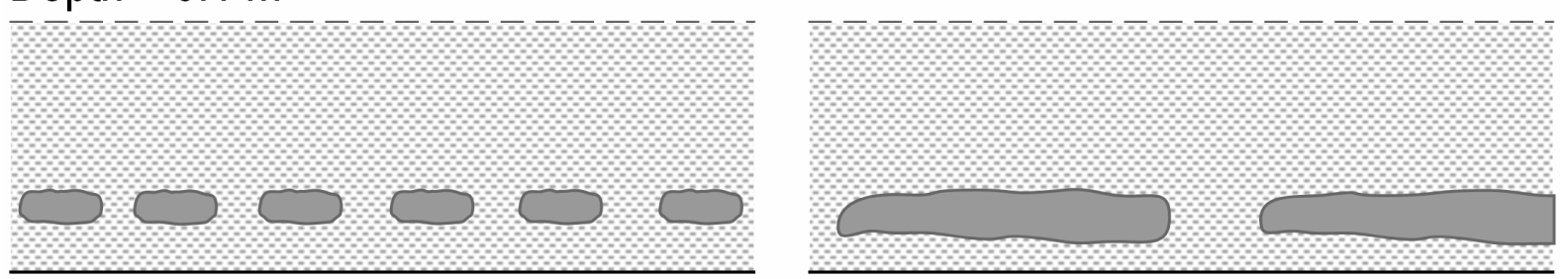

Figure 2. Simulated positions of subsurface rock fragments in the topsoil: control experiment and rock fragments incorporated in the topsoil at a depth of $0.001,0.01,0.05$ and $0.1 \mathrm{~cm}$; rock fragment cover equals 60\%; RFS: rock fragment size. Depth represents the depth of the rock fragments below the soil surface. 


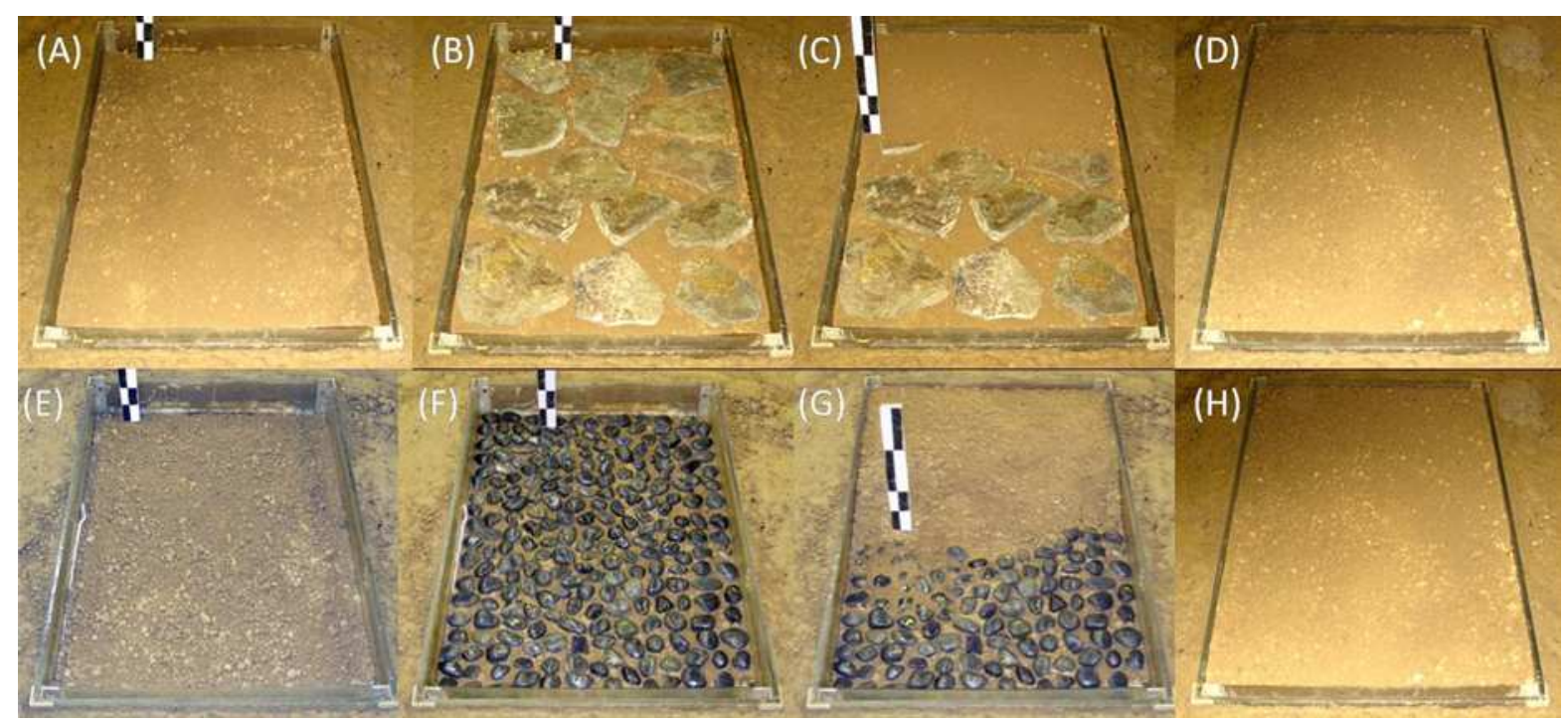

Figure 3. Interrill flume preparation procedure for (Fig. A-D) rock fragments (RFS $=0.20 \mathrm{~m}$ ) at a depth of $0.05 \mathrm{~m}$ below the soil surface and for (Fig. E-H) rock fragments (RFS $=0.04 \mathrm{~m}$ ) at a depth of $0.10 \mathrm{~m}$ below the soil surface: (A, E) first layer of air-dried sieved soil, (B, F) rock fragments are randomly applied on the first soil layer with a cover of $60 \%,(\mathrm{C}, \mathrm{G})$ rock fragments are covered with soil and, $(\mathrm{D}, \mathrm{H})$ the soil surface is flattened. Dimensions of interrill flume are 0.94 by $0.60 \mathrm{~m}$.
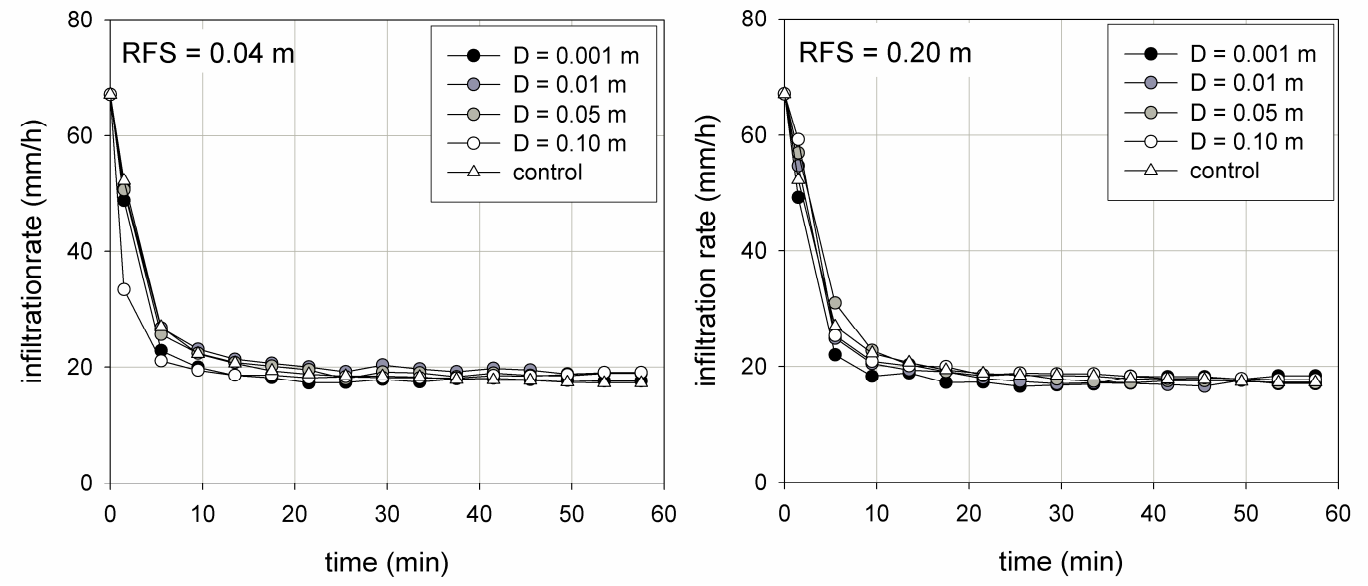

Figure 4. Mean infiltration rates during simulated rainfall (at $67 \mathrm{~mm} \mathrm{~h}^{-1}$ ) for the two tested rock fragment sizes (RFS) at different depths (D) below the soil surface. 

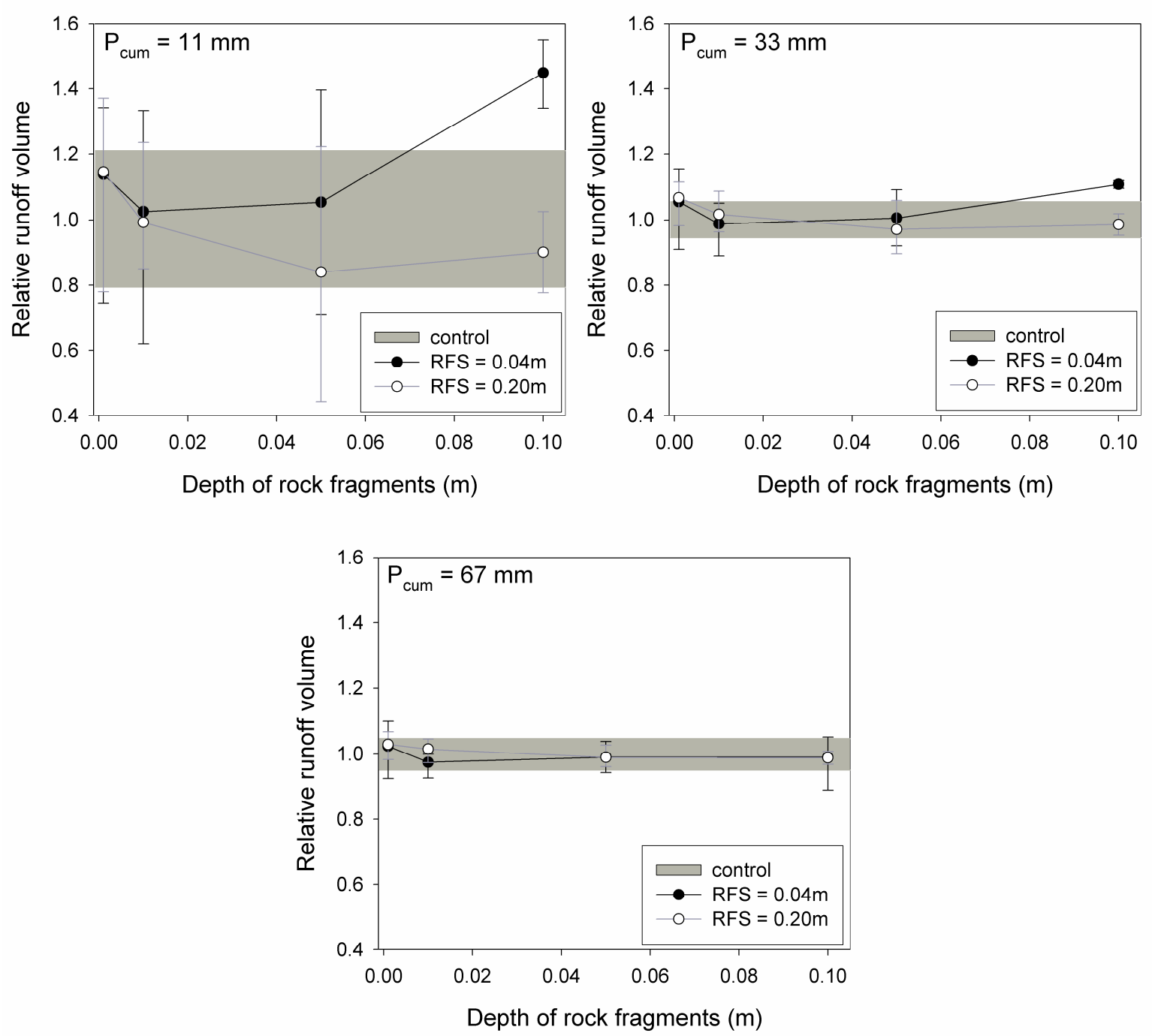

Figure 5. Relative mean, minimum and maximum cumulative runoff volume obtained after 11,33 and $67 \mathrm{~mm}$ of cumulative rainfall depth $\left(\mathrm{P}_{\text {cum }}\right)$ in relation to the mean runoff volume for the control (without subsurface rock fragments) for the two rock fragment sizes (RFS) at different depths below the soil surface. Shaded area represents values between the minimum and the maximum runoff volume for the control treatment. 

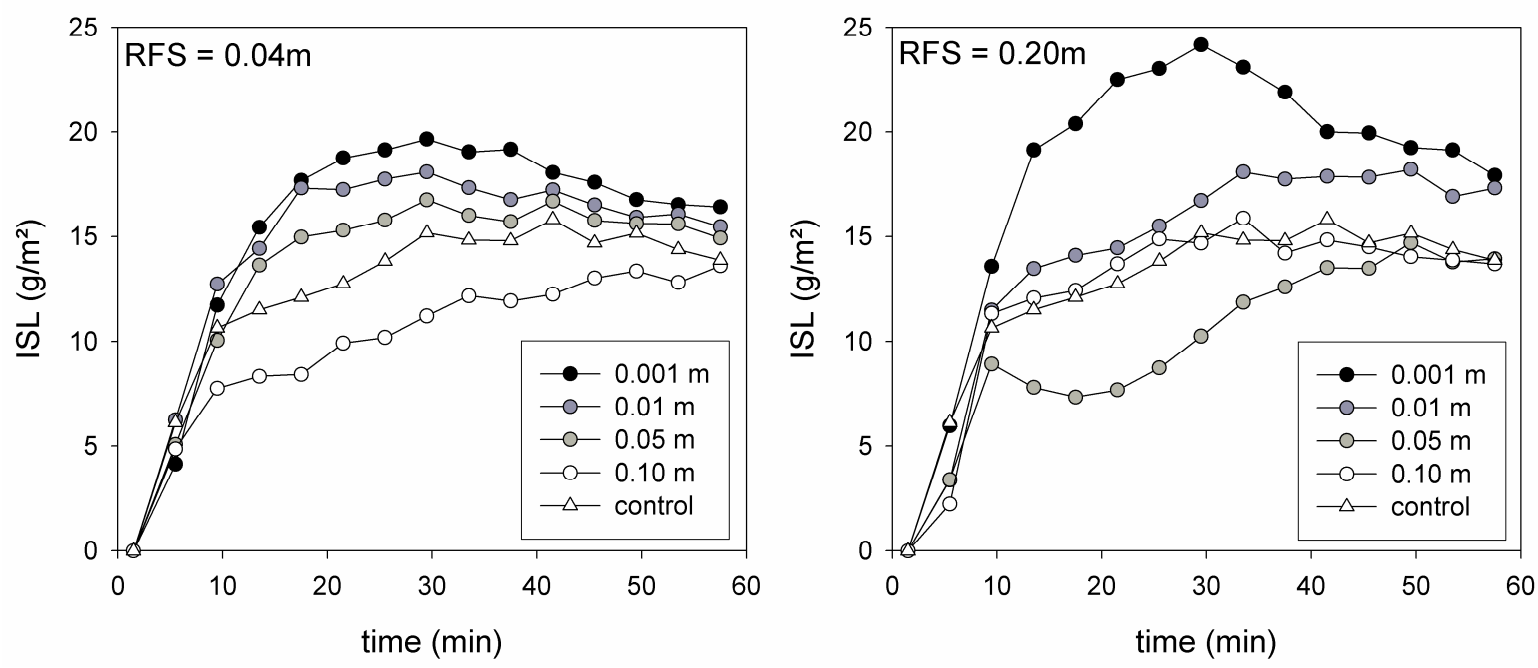

Figure 6. Mean interrill soil loss rates (ISL) obtained during the rainfall simulations for the two tested rock fragment sizes (RFS) at different depths below the soil surface. 

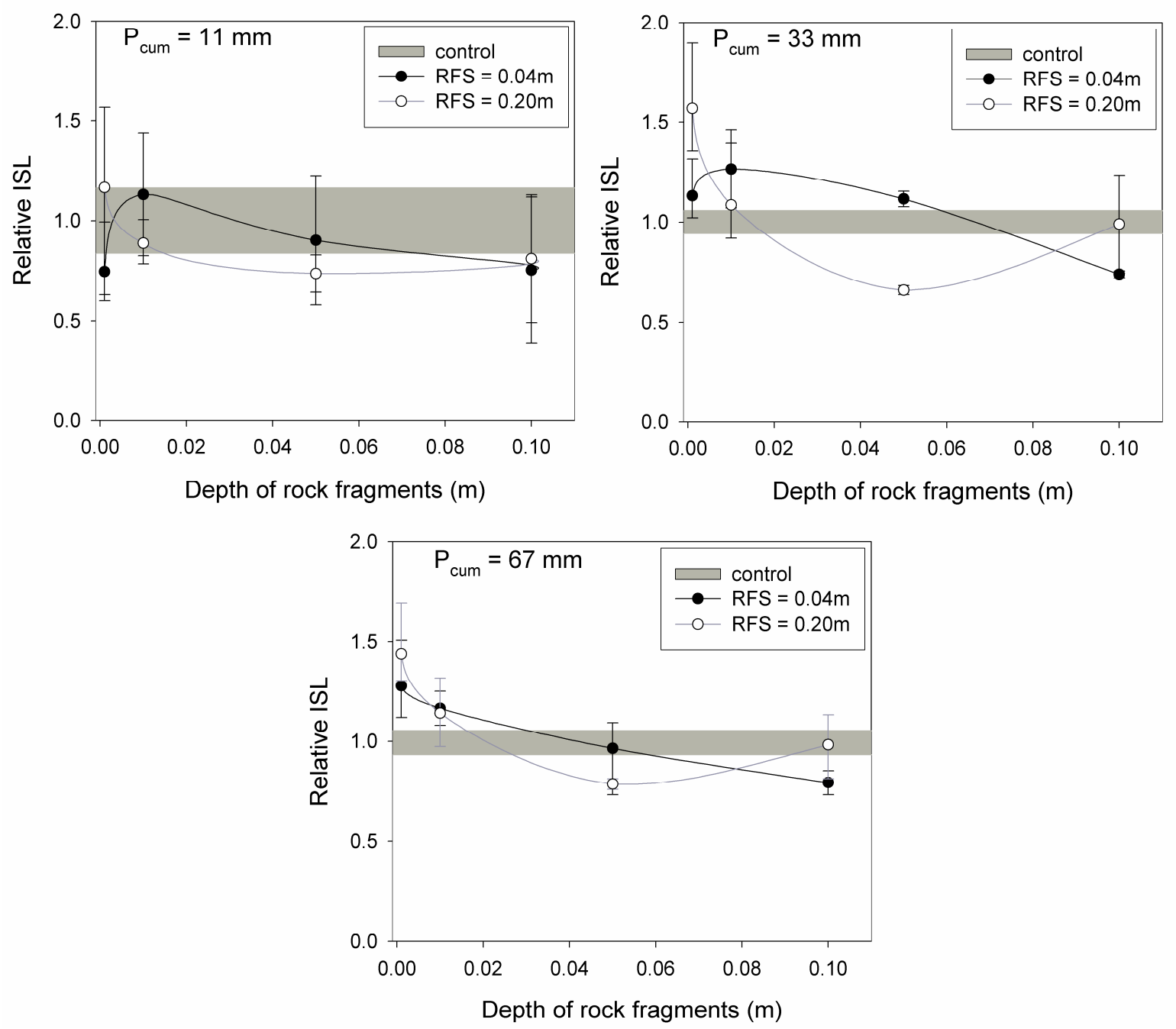

Figure 7. Relative mean, minimum and maximum cumulative interrill soil loss (ISL) obtained after 11, 33 and 67 of cumulative rainfall depth $\left(\mathrm{P}_{\text {cum }}\right)$ in relation to the mean interrill soil loss for the control (without subsurface rock fragments) for the two rock fragment sizes (RFS) at different depths below the soil surface. Shaded area represents values between the minimum and the maximum ISL for the control treatment. 

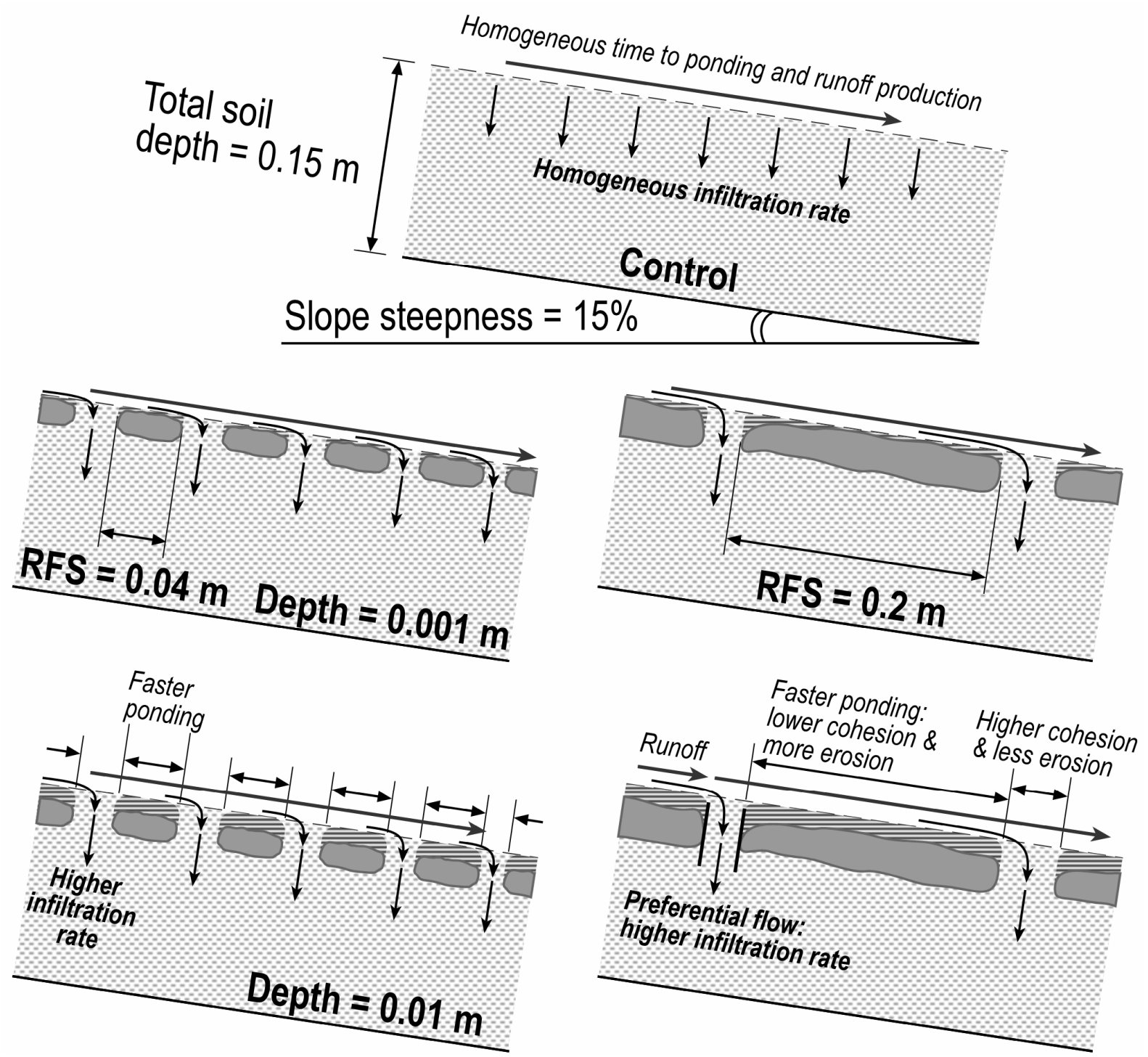

Figure 8. Conceptual model indicating infiltration and runoff processes for a control topsoil profile (without subsurface rock fragments) and on topsoil profiles with subsurface rock fragments, having two sizes, at different depths below the soil surface. An increase in soil moisture in the areas above the rock fragments leads to rapid topsoil saturation, ponding and a decrease in soil cohesion. Rock fragment cover equals 60\%; Depth represents the depth of the rock fragments below the soil surface. 